\title{
Effect of Broussonetia papyrifera L. (paper mulberry) silage on dry matter intake, milk composition, antioxidant capacity and milk fatty acid profile in dairy cows
}

\author{
Bingwen $\mathrm{Si}^{1,2, a}$, Hui Tao ${ }^{1, a}$, Xiaoli Zhang ${ }^{3}$, Jiangpeng Guo ${ }^{4}$, Kai Cui ${ }^{1}$, Yan Tu${ }^{1}$, and Qiyu Diao ${ }^{1, *}$
}

\footnotetext{
* Corresponding Author: Qiyu Diao

Tel: +1-336-285-4807, Fax: +1-336-334-7288,

E-mail: soh@ncat.edu

${ }^{1}$ Feed Research Institute, Chinese Academy of Agricultural Sciences, Key Laboratory of Feed Biotechnology of the Ministry of Agriculture, Beijing 10081, China

${ }^{2}$ National Engineering Research Center of Biological Feed, Beijing 10081, China

${ }^{3}$ Beijing Plant Protection Station, Beijing 100029, China

${ }^{4}$ Beijing Animal Husbandry Station, Beijing 100029, China
}

a These authors contributed equally to this research and should be considered co-first authors.

ORCID

Bingwen $\mathrm{Si}$

https://orcid.org/0000-0001-5050-7078

Hui Tao

https://orcid.org/0000-0003-3981-9251

Xiaoli Zhang

https://orcid.org/0000-0002-2969-7337

Jiangpeng Guo

https://orcid.org/0000-0002-0786-064X

Kai Cui

https://orcid.org/0000-0002-6885-952X

Yan Tu

https://orcid.org/0000-0002-4324-6188

Qiyu Diao

https://orcid.org/0000-0002-8037-1471

Submitted Nov 20, 2017; Revised Dec 18, 2017: Accepted Jan 26, 2018
Objective: This study was carried out to investigate the possible application of Broussonetia papyrifera (B. papyrifera) silage as a functional feeding stuff in dairy cattle.

Methods: Seventy-two Holstein cows were divided into four groups randomly and allocated to 6 pens with 3 individuals in each group and fed the original total mixed ratio (TMR) in the dairy farm or the new TMR with 5\%, 10\%, and 15\% B. papyrifera silage, separately. Feed intake were recorded, milk and blood samples were collected, and milk composition, blood metabolites and milk fatty acids composition were measure at the end of the experiment.

Results: Dry matter intake of cows decreased when they fed on diet with B. papyrifera, but no differences were observed in body condition score, milk yield, milk protein and lactose, feed efficiency and serum metabolites between groups. Both $10 \%$ or $15 \%$ of B. papyrifera silage in the diet significantly increased the immunoglobulin A (IgA) and IgG in serum, 15\% of $B$. papyrifera silage increased the content of serum catalase, superoxide dismutase, total antioxidant capacity, and decreased the content of 8-hydroxy-2'-deoxyguanosine. Furthermore, $10 \%$ or $15 \%$ of B. papyrifera silage resulted in a significant decrease in the milk somatic cell count, and increased the polyunsaturated fatty acids content in the milk.

Conclusion: The diets with $10 \%$ to $15 \%$ of $B$. papyrifera silage might enhance the immune and antioxidant function of dairy cows and increase the polyunstaturated fatty acid concentration in the milk.

Keywords: Broussonetia papyrifera Silage; Immune Function; Antioxidant Capacity; Milk; Dairy Cows

\section{INTRODUCTION}

Animal husbandry practices are closely linked with animal health, production and welfare. Intensive model of farm animal husbandry brings high yields, but compromises animal health and welfare which might increase the incidence of diseases. For ruminants, there are great opportunities to explore antioxidant enriched forage.

Broussonetia papyrifera L. (B. papyrifera, paper mulberry) is a deciduous tree or shrub in the family Moraceae that is native to eastern Asia, and widespread in China, which can be used as a food or a source of traditional medicine to treat various diseases for both humans and animals. Also the B. papyrifera L. fruits polysaccharides have antioxidant and antibacterial activities [1]. And it is reported that the radix of B. papyrifera L. had the greatest antinociceptive and anti-inflammatory effects when different parts of the plant were compared as treatment for chemical-induced pain and inflammation in rodents [2]. B. papyrifera $L$. had a protective effect against hydrogen peroxide-induced oxidative stress in human $\mathrm{SH}$ SY5Y cells [3]. Prenylflavone derivatives from B. papyrifera $L$. were found to inhibit the 
growth of breast cancer cells in vitro and in vivo, which showed that they had potent anti-tumor activity [4]. There are about 300,000 hectares of B. papyrifera in China, which are a potential resource of animal feeding with economical and practical merits. Many of the plants contain phytochemicals, which have potent antioxidant activities [1,5-8]. Antioxidant activities have been described for related polyphenolic constituents extracted from the stem, bark and wood of B. papyrifera L. [9]. It is reported that intake of high total antioxidant capacity (TAC) plants might be beneficial for the TAC status of cattle, and mean TAC levels in shrubs and trees were higher than those in grass, concentrate and timothy hay [10,11]. It has been suggested that flavonoids, a major class of plant secondary metabolites with many functions, such as pigmentation, antimicrobial activity and antioxidant activity [12], widely present in the plant kingdom, play an important role in disease prevention [13]. Oxidative stress has no clinical symptoms but is particularly dangerous in animals. Some defense mechanisms are available to prevent oxidative damage, including some enzymes, glutathione peroxidase (GSH-Px), superoxide dismutase (SOD), TAC, and catalase (CAT). Dietary antioxidants are vital components in preventing damage by free radicals in the body, like reactive oxygen species $[14,15]$. The objective of this study was to investigate the effects of $B$. papyrifera silage on the dry matter intake, blood plasma metabolites, immune function, antioxidant capacity and milk fatty acid (FA) profile in dairy cattle and to provide practical evidence supporting the application of B. papyrifera silage in the diet of dairy cows.

\section{MATERIALS AND METHODS}

The experimental protocol was approved by the Chinese Academy of Agricultural Sciences Animal Ethics Committee, which was performed in accordance with animal welfare practices and procedures followed the Guidelines for Experimental Animal of the Ministry of Science and Technology (2006, Beijing, China).

\section{Animal and management}

The whole foliage of $B$. papyrifera was mowed with $20 \mathrm{~cm}$ of stubble left from saplings of about $1.8 \mathrm{~m}$ height. The whole crop was ensiled without additive after chopping to a length of $2.5 \pm 1.5 \mathrm{~cm}$, The B. papyrifera silage was fermented for 45 days before being used for the feeding experiment. Seventytwo Holstein cows with initial day in milk (DIM) $=128 \pm 65$ $\mathrm{d}$, body weight $=572 \pm 29 \mathrm{~kg}$, milk yield $=32.16 \pm 0.95 \mathrm{~kg}$ and milk somatic cell counts $($ SCC $)=158 \times 10^{3} \pm 35 \times 10^{3}$ cells $/ \mathrm{mL}$ were divided into four groups randomly according to day in milk, parity, milk yield, and milk SCC, and allocated in 6 pens with 3 individuals in each group and given ad libitum access to feed and water. The cattle in the control group were fed on the original total mixed ratio (TMR) in the dairy farm, and the other 3 treatment groups were fed on the new TMR with 5\% (Group low [Group L]), 10\% (Group middle [Group M]), or 15\% (Group high [Group H]) of B. papyrifera silage preparation, separately. The four different TMRs were adjusted as isonitrogenous and isoenergetic diets, with the composition shown in Table 2 . The cattle were fed approximately $110 \%$ of expected consumption at 8:00 and 17:00 separately, and the residual was collected before the next feeding and then weighed and recorded. The delivery amount was adjusted according to the previous day's consumption. Cows were milked at 6:00, 13:00, and 19:30 in the milking parlor. The feeding adaption period was 7 days, and the experiment period was 42 days. The body condition score was measured by 2 evaluators and scores were averaged.

\section{Measurements and analysis}

The composited dietary samples, including feeding ingredients, TMRs and residual, were collected on fresh matter basis every 2 weeks during the experimental period. The samples were dried in an oven at $65^{\circ} \mathrm{C}$ for $48 \mathrm{~h}$, then kept at room temperature for $24 \mathrm{~h}$, and ground to pass through 40-mesh sieve. Dry matter (DM), crude fat (ether extract), ash, neutral detergent fiber (NDF), acid detergent fiber (ADF) were determined according to the methods reported by van Soest et al [16] and Goering and Van Soest [17], respectively.

The $\mathrm{pH}$ value of $B$. papyrifera silage was 5.04 and the nutrient composition of $B$. papyrifera silage was $29.06 \%$ of DM, $15.01 \%$ of crude protein (CP), $58.78 \%$ of NDF, $32.15 \%$ of ADF, $6.17 \%$ of ash at DM basis (Table 1), and 4 different TMRs are shown in Table 2. Milk yield was recorded every day, and milk samples were collected weekly, $40 \mathrm{~mL}$ of the milk was added with Potassium Dichromate for preservation and kept in $-4^{\circ} \mathrm{C}$ for milk component analysis. Protein, fat and lactose concentrations in milk were determined with a Foss MilkoScanFT 6000 Analyzer (Foss Electric A/S, Hillerod, Denmark), and SCC were determined with a Foss Matic FM5000 instrument (Foss Electric, Denmark).

Another $50 \mathrm{~mL}$ of milk was frozen at $-20^{\circ} \mathrm{C}$ without preservative for FA profile analysis. Total lipids in milk were extracted according to the method reported by Bligh and Dyer [18], then FAs were methylated into fatty acid methyl esters (FAME) according to the method described by Carrapiso et al [19]. The FA profile was determined by gas chromatography (GC, Shimadzu GC-2010, Kyoto, Japan) equipped with flame ion-

Table 1. The pH value and nutrient composition of Broussonetia papyrifera silage

\begin{tabular}{lccccc}
\hline pH value & DM & $\begin{array}{c}\text { CP } \\
(\% \text { DM) }\end{array}$ & $\begin{array}{c}\text { NDF } \\
(\% \text { DM) }\end{array}$ & $\begin{array}{c}\text { ADF } \\
(\% \text { DM })\end{array}$ & $\begin{array}{c}\text { Ash } \\
(\% \text { DM })\end{array}$ \\
\hline 5.04 & 29.06 & 15.01 & 58.78 & 32.15 & 6.17 \\
\hline $\begin{array}{l}\text { DM, dry matter; } C P \text {, crude protein; NDF, neutral detergent fiber; ADF, acid deter- } \\
\text { gent fiber. }\end{array}$
\end{tabular}


Table 2. Nutrient composition of the diets

\begin{tabular}{|c|c|c|c|c|}
\hline Item & Control & Group L & Group M & Group H \\
\hline \multicolumn{5}{|c|}{ Ingredients ( $\%$ of DM basis) } \\
\hline B. papyrifera silage & 0 & 5 & 10 & 15 \\
\hline Whole corn silage & 23.99 & 16.65 & 10.34 & 4.03 \\
\hline Alfalfa hay & 15.15 & 11.56 & 8.01 & 4.46 \\
\hline Oat hay & 4.54 & 10.47 & 15.33 & 20.19 \\
\hline Beet pulp pellet & 3.80 & 3.80 & 3.80 & 3.80 \\
\hline Whole cottonseed & 7.60 & 7.60 & 7.60 & 7.60 \\
\hline Corn & 22.05 & 22.05 & 22.05 & 22.05 \\
\hline Soybean meal & 7.75 & 7.75 & 7.75 & 7.75 \\
\hline Wheat bran & 3.80 & 3.80 & 3.80 & 3.80 \\
\hline Cottonseed meal & 1.8 & 1.8 & 1.8 & 1.8 \\
\hline Rapeseed mean & 3.0 & 3.0 & 3.0 & 3.0 \\
\hline DDGS & 4.5 & 4.5 & 4.5 & 4.5 \\
\hline $\mathrm{NaHCO}_{3}$ & 0.6 & 0.6 & 0.6 & 0.6 \\
\hline Limestone & 0.6 & 0.6 & 0.6 & 0.6 \\
\hline $\mathrm{CaHPO}_{4} \cdot 2 \mathrm{H}_{2} \mathrm{O}$ & 0.30 & 0.30 & 0.30 & 0.30 \\
\hline $\mathrm{NaCl}$ & 0.22 & 0.22 & 0.22 & 0.22 \\
\hline Premix ${ }^{11}$ & 0.3 & 0.3 & 0.3 & 0.3 \\
\hline Total & 100 & 100 & 100 & 100 \\
\hline \multicolumn{5}{|l|}{ Chemical composition } \\
\hline $\mathrm{DM}(\%)$ & 52.81 & 51.05 & 50.92 & 50.66 \\
\hline $\mathrm{CP}(\%)$ & 15.71 & 15.84 & 15.60 & 15.94 \\
\hline $\mathrm{NE}_{\mathrm{L}}(\mathrm{MJ} / \mathrm{kg} \text { of } \mathrm{DM})^{2)}$ & 7.46 & 7.52 & 7.55 & 7.48 \\
\hline $\mathrm{EE}(\%)$ & 2.18 & 2.74 & 2.11 & 2.29 \\
\hline $\operatorname{NDF}(\%)$ & 29.08 & 28.95 & 29.69 & 28.87 \\
\hline $\operatorname{ADF}(\%)$ & 17.73 & 19.44 & 18.55 & 17.98 \\
\hline Ash (\%) & 7.29 & 7.85 & 7.45 & 7.46 \\
\hline
\end{tabular}

DDGS, distillers dried grains with solubles; $D M$, dry matter; $C P$, crude protein; $\mathrm{NE}_{\mathrm{L}}$ net energy-lactation; $E E$, ether extract; NDF, neutral detergent fiber; ADF, acid detergent fiber.

1) The premix contains the following: Vit A 600,000 IU; Vit D 100,000 IU; Vit E 4,000 IU; Fe 3,000 mg; Cu 2,000 mg; Mn 2,500 mg; Zn 8,000 mg; Se 60 mg; I 100 mg; Co $20 \mathrm{mg}$ per kilogram.

${ }^{2)} \mathrm{NE}_{L}$ was a calculated value, while the others were measured values.

ization detector and split injection, $100 \mathrm{~m}$ length, $0.25 \mathrm{~mm}$ i.d., $0.2 \mu \mathrm{m}$ thickness capillary GC column (SP-2560; Supelco Inc., Bellefonte, PA, USA).The initial oven temperature was $100^{\circ} \mathrm{C}$, which was held for $13 \mathrm{~min}$, then increased to $180^{\circ} \mathrm{C}$ at a rate of $10^{\circ} \mathrm{C}$ and held for $6 \mathrm{~min}$, then increased to $200^{\circ} \mathrm{C}$ at $1^{\circ} \mathrm{C} / \mathrm{min}$ and held for $20 \mathrm{~min}$, and then increased to 230 at $4^{\circ} \mathrm{C} / \mathrm{min}$ and held for $15.5 \mathrm{~min}$. High purity nitrogen was used as carrier gas at a flow rate of $1 \mathrm{~mL} / \mathrm{min}$. The injector was set at $270^{\circ} \mathrm{C}$, and the detector was set at $280^{\circ} \mathrm{C}$. FAMEs were identified by compared with the retention times of the standards. The standards were FAME MixC4-C24 Unsatures (Sigma 18919, Germany).

Six blood samples $(10 \mathrm{~mL})$ were collected into lithium heparin Vacutainer tubes (Becton, Dickinsonand Company, Franklin Lakes, NJ, USA) using jugular venipuncture before feeding on $\mathrm{d} 4$ during each week. Samples were centrifuged at $3,500 \mathrm{rpm}$ for 20 minutes; the serum was aspirated and kept at $-20^{\circ} \mathrm{C}$ for analysis of metabolites, immune and antioxidation capacity. Metabolite, immune parameters and anti-oxidation biomarkers were determined by a biochemical auto-analyzer (Hitachi automatic biochemical analyzer 7600, Tokyo, Japan) using commercially available kits: glucose (GLU), total protein (TP), albumin (ALB), globulin (GLB), non-esterified fatty acid (NEFA), blood urea nitrogen (BUN), immunoglobulin A (IgA), IgG, IgM, CAT, SOD, GSH-Px, TAC, and malondialdehyde (MDA) according to the manufacturer's instructions. The activity of tumor necrosis factor a were measured by a micro plate reader (BioTek ELX800, BioTek, Winooski, VT, USA) with commercially available kits.

\section{Statistical analysis}

The data were compared using one-way analysis of variance with Duncan's multiple comparisons. Significance was set at $\mathrm{p}<0.05$ using SAS version 9.2 (SAS Institute Inc., Gary, NC, USA), and the data were expressed as mean and accompanied by standard error of the mean.

\section{RESULTS}

\section{Milk yield and composition}

As shown in Table 3, cows fed on diets with B. papyrifera silage had lower dry matter intake (DMI) than those fed on

Table 3. Effects of Broussonetia papyrifera silage on DMI, feed efficiency, milk yield and milk composition

\begin{tabular}{|c|c|c|c|c|c|c|}
\hline \multirow{2}{*}{ Item } & \multicolumn{4}{|c|}{ Treatment } & \multirow{2}{*}{ SEM } & \multirow{2}{*}{ p-value } \\
\hline & Control & Group L & Group M & Group H & & \\
\hline $\mathrm{DMI}(\mathrm{kg} / \mathrm{d})$ & $22.27^{a}$ & $21.31^{b}$ & $19.93^{c}$ & $18.41^{d}$ & 0.167 & $<0.0001$ \\
\hline body condition score & 3.52 & 3.36 & 3.63 & 3.47 & 0.180 & 0.753 \\
\hline Milk yield (kg/d) & 32.65 & 32.05 & 31.76 & 30.74 & 0.278 & 0.098 \\
\hline Feed efficiency & 1.46 & 1.52 & 1.59 & 1.67 & 0.030 & 0.318 \\
\hline Milk fat (\%) & 3.64 & 3.72 & 3.87 & 3.91 & 0.042 & 0.093 \\
\hline Milk protein (\%) & 3.32 & 3.30 & 3.34 & 3.23 & 0.023 & 0.333 \\
\hline Milk lactose (\%) & 4.99 & 4.91 & 5.01 & 5.02 & 0.011 & 0.132 \\
\hline Milk SCC ( $10^{3}$ cells $\left./ \mathrm{mL}\right)$ & $183.83^{\mathrm{a}}$ & $151.87^{\mathrm{a}}$ & $105.23^{b}$ & $81.74^{c}$ & 10.330 & 0.003 \\
\hline
\end{tabular}

DMI, dry matter intake; SEM, standard error of the mean; SCC, somatic cell count.

${ }^{a-c}$ Means within row with different superscripts differ significantly $(p<0.05)$. 
diet without B. papyrifera silage $(\mathrm{p}<0.05)$, and cows had lower $\mathrm{DMI}$ as the $B$. papyrifera silage increased in the diet $(\mathrm{p}<0.05)$. Cows had similar feed efficiency in control group and treatment groups $(\mathrm{p}>0.05)$. There was no difference between groups in milk yield, milk fat, protein and lactose ( $p>0.05$ ), while cows in Group M and Group H had significantly lower milk SCC than that in control group and Group L $(\mathrm{p}<0.05)$.

Blood metabolites, immune, and antioxidant functions Parameters of serum are presented in Table 4. No significant differences were found in TP, ALB, GLB, NEFA, BUN, GLU, GSH-Px, MDA ( $p>0.05$ ) between groups. Compared with the control, $10 \%$ and $15 \%$ of $B$. papyriferasilage significantly increased the concentration of IgA and $\operatorname{IgG}(\mathrm{p}<0.05)$, and $15 \%$ of $B$. papyrifera silage significantly increased the concentration of $\operatorname{IgM}(\mathrm{p}<0.05)$, and $15 \%$ of $B$. papyrifera silage significantly increased CAT, SOD, and TAC in the serum $(\mathrm{p}<0.05)$. But serum CAT, SOD, and TAC activity of cows was not affected by the diet with $10 \%$ or $15 \%$ B. papyrifera silage.

\section{Milk fatty acid profiles}

Compared with the control, $15 \%$ of B. papyrifera silage diets significantly decreased C4:0 and C17:0 content in milk fat $(\mathrm{p}<0.05)$, increased C18:1n9c and polyunstaturated fatty acid (PUFA) concentration in the milk $(\mathrm{p}<0.05)$ as shown in Table 5.

\section{DISCUSSION}

\section{Milk yield and composition}

DMI of cattle in the experiment decreased significantly ( $\mathrm{p}<$ 0.05 ) as the content of B. papyrifera silage increased in the diet. The palatability of $B$. papyrifera silage might not be as good as the hay silage or flavonoids exceeded a certain level which affected the DMI of the cattle in the Group L, Group M, and Group H. However, with a lower DMI of cattle fed with $B$. papyrifera silage, the feed efficiency and milk yield were not affected ( $p>0.05)$. The SCC in milk is an indicator reflecting mammary health and milk quality. The physiological level of SCC in bulk cow milk is between $50 \times 10^{3}$ and $100 \times 10^{3}$ cells per $\mathrm{mL}$, whereas $200 \times 10^{3}$ cells per $\mathrm{mL}$ is taken as the threshold to define a mammary quarter between healthy and infected [20,21]. In the present study, Group M and Group H had lower milk SCC than that of the control Group and Group L, which might due to the anti-inflammatory effect of the active ingredients in B. papyrifera [22-24]. It is reported that high content of milk protein was found in high SCC milk [25] and fat content was significantly increased from $3.55 \%$ to $3.72 \%$ by an increment of SCC from 100 to 200 cells/mL [26], but a decrease of milk protein content when SCC in milk was high [5]. Lactose content in high-SCC milk was significantly lower [27] which could be a result of reduced synthesis because of the inflammation processes. In our study, no significant differ-

Table 4. Effects of Broussonetia papyrifera silage silage on serum indexes

\begin{tabular}{|c|c|c|c|c|c|c|}
\hline \multirow{2}{*}{ Item } & \multicolumn{4}{|c|}{ Treatment } & \multirow{2}{*}{ SEM } & \multirow{2}{*}{$\mathrm{p}$-value } \\
\hline & Control & Group L & Group M & Group H & & \\
\hline \multicolumn{7}{|l|}{ Serum metabolites } \\
\hline $\mathrm{TP}(\mathrm{g} / \mathrm{L})$ & 57.98 & 59.32 & 56.97 & 54.87 & 2.153 & 0.915 \\
\hline$A L B(g / L)$ & 22.07 & 21.75 & 21.22 & 20.55 & 0.618 & 0.852 \\
\hline $\mathrm{GLB}(\mathrm{g} / \mathrm{L})$ & 35.92 & 37.57 & 35.75 & 34.32 & 1.663 & 0.933 \\
\hline $\operatorname{NEFA}(\mu \mathrm{mol} / \mathrm{L})$ & 445.64 & 386.80 & 480.29 & 369.18 & 31.585 & 0.601 \\
\hline BUN (mmol/L) & 3.87 & 3.55 & 3.44 & 4.10 & 0.138 & 0.329 \\
\hline $\mathrm{GLU}(\mathrm{mmol} / \mathrm{L})$ & 3.38 & 3.72 & 2.83 & 2.56 & 0.268 & 0.438 \\
\hline \multicolumn{7}{|l|}{ Immune parameters } \\
\hline $\lg A(g / L)$ & $0.82^{b}$ & $0.80^{\mathrm{b}}$ & $0.99^{\mathrm{a}}$ & $1.00^{\mathrm{a}}$ & 0.029 & 0.008 \\
\hline $\lg G(g / L)$ & $8.29^{b}$ & $9.23^{\mathrm{ab}}$ & $9.75^{\mathrm{a}}$ & $10.16^{\mathrm{a}}$ & 0.218 & 0.013 \\
\hline $\lg M(g / L)$ & $0.75^{b}$ & $0.77^{b}$ & $0.81^{a b}$ & $0.86^{\mathrm{a}}$ & 0.014 & 0.017 \\
\hline $\mathrm{TNFa}(\mathrm{ng} / \mathrm{mL})$ & 1.67 & 1.89 & 1.93 & 2.00 & 0.063 & 0.357 \\
\hline \multicolumn{7}{|c|}{ Anti-oxidation biomarkers } \\
\hline CAT (U/mL) & $3.96^{b}$ & $4.26^{b}$ & $4.80^{\mathrm{ab}}$ & $5.77^{\mathrm{a}}$ & 0.209 & 0.008 \\
\hline $\mathrm{SOD}(\mathrm{U} / \mathrm{mL})$ & $136.73^{b}$ & $140.98^{b}$ & $141.83^{\mathrm{ab}}$ & $152.47^{\mathrm{a}}$ & 2.099 & 0.041 \\
\hline $\mathrm{TAC}(\mathrm{U} / \mathrm{ml})$ & $9.25^{b}$ & $10.58^{\mathrm{ab}}$ & $10.71^{\mathrm{a}}$ & $11.39^{\mathrm{a}}$ & 0.271 & 0.024 \\
\hline GSH-Px (U/mL) & 844.72 & 886.18 & 856.10 & 848.78 & 10.107 & 0.486 \\
\hline $8-\mathrm{OHdG}(\mathrm{ng} / \mathrm{mL})$ & $0.49^{\mathrm{a}}$ & $0.44^{\mathrm{ab}}$ & $0.39^{b c}$ & $0.33^{c}$ & 0.017 & 0.001 \\
\hline MDA ( $\mu \mathrm{mol} / \mathrm{L})$ & 5.88 & 5.65 & 5.03 & 5.19 & 0.205 & 0.437 \\
\hline
\end{tabular}

SEM, standard error of the mean; TP, total protein; ALB, albumin; GLB, globulin; NEFA, non-esterified fatty acid; BUN, urea nitrogen; GLU, glucose; IgG, immunoglobulin G; IgA, immunoglobulin A; IgM, immunoglobulin M; TNFa, tumor necrosis factor $\alpha$; CAT, catalase; SOD, superoxide dismutase; TAC, total antioxidant capacity; GSH-Px, glutathione peroxidase; 8-OHdG, 8-hydroxy-2'-deoxyguanosine; MDA, malondialdehyde.

a-c Means within row with different superscripts differ significantly $(p<0.05)$. 
Table 5. Effects of Broussonetia papyrifera silage on milk fatty acid profiles

\begin{tabular}{|c|c|c|c|c|c|c|}
\hline \multirow{2}{*}{$\begin{array}{l}\text { Item } \\
\text { (mg/g total lipid) }\end{array}$} & \multicolumn{4}{|c|}{ Treatment } & \multirow{2}{*}{ SEM } & \multirow{2}{*}{$p$-value } \\
\hline & Control & Group L & Group M & Group H & & \\
\hline$C 4: 0$ & $1.39^{\mathrm{a}}$ & $1.25^{\mathrm{a}}$ & $1.08^{b}$ & $0.86^{c}$ & 0.046 & $<0.000$ \\
\hline $\mathrm{C}: 0$ & 1.49 & 1.31 & 1.34 & 1.47 & 0.031 & 0.161 \\
\hline $\mathrm{C} 8: 0$ & 1.16 & 1.13 & 1.09 & 1.07 & 0.024 & 0.755 \\
\hline $\mathrm{C} 10: 0$ & 3.27 & 3.26 & 3.05 & 2.95 & 0.076 & 0.540 \\
\hline C12:0 & 4.29 & 4.22 & 3.83 & 3.63 & 0.104 & 0.057 \\
\hline C13:0 & 0.27 & 0.30 & 0.27 & 0.21 & 0.012 & 0.109 \\
\hline C14:0 & 14.58 & 14.90 & 14.66 & 13.95 & 0.190 & 0.364 \\
\hline C14:1 & 1.21 & 1.16 & 1.15 & 0.86 & 0.064 & 0.196 \\
\hline C15:0 & 1.49 & 1.50 & 1.54 & 1.34 & 0.045 & 0.434 \\
\hline C16:0 & 39.04 & 39.82 & 39.27 & 38.35 & 0.482 & 0.090 \\
\hline C16:1 & 1.76 & 1.56 & 1.61 & 1.53 & 0.072 & 0.753 \\
\hline C17:0 & $0.79^{\mathrm{a}}$ & $0.70^{\mathrm{a}}$ & $0.61^{\mathrm{ab}}$ & $0.47^{b}$ & 0.041 & 0.026 \\
\hline $\mathrm{C} 18: 0$ & 10.28 & 9.53 & 10.25 & 11.63 & 0.418 & 0.119 \\
\hline C18:1n9c & $15.09^{b}$ & $15.29^{b}$ & $15.82^{\mathrm{ab}}$ & $17.12^{\mathrm{a}}$ & 0.295 & 0.042 \\
\hline C18:2n6c & 2.81 & 2.90 & 3.22 & 3.39 & 0.096 & 0.138 \\
\hline$C 18: 3 n 3$ & 0.30 & 0.32 & 0.39 & 0.32 & 0.017 & 0.256 \\
\hline$C 20: 3 n 6$ & 0.17 & 0.18 & 0.19 & 0.18 & 0.014 & 0.489 \\
\hline$C 20: 4 n 6$ & 0.23 & 0.22 & 0.28 & 0.27 & 0.011 & 0.151 \\
\hline C21:0 & 0.38 & 0.45 & 0.35 & 0.40 & 0.016 & 0.224 \\
\hline SFA ( $\%$ total FA) & 78.43 & 78.37 & 77.34 & 76.33 & 0.382 & 0.057 \\
\hline UFA ( $\%$ total FA) & 21.57 & 21.63 & 22.66 & 23.67 & 0.353 & 0.203 \\
\hline PUFA ( $\%$ total FA) & $3.51^{\mathrm{b}}$ & $3.62^{\mathrm{ab}}$ & $4.08^{\mathrm{a}}$ & $4.16^{\mathrm{a}}$ & 0.103 & 0.025 \\
\hline MUFA ( $\%$ total FA) & 18.06 & 18.01 & 18.58 & 19.51 & 0.328 & 0.226 \\
\hline
\end{tabular}

SEM, standard error of the mean; SFA, saturated fatty acid; FA, fatty acid; UFA, unsaturated fatty acid; PUFA, polyunstaturated fatty acid; MUFA, monounsaturated fatty acid.

${ }^{a-c}$ Means within row with different superscripts differ significantly $(p<0.05)$.

ences in milkfat, protein and lactose was found in difference levels of milk SCC which is consistent with the result reported by Mazal et al [28]. There might be no connection between the SCC and protein content in milk when the udders of cows are not infected.

Blood metabolites, immune and antioxidant functions Blood metabolites represent an integrated index of nutrient supply in relation to the utilization of nutrients. In the present study, no significant difference was found in the serum TP, ALB, GLB, NEFA, BUN, and GLU between groups ( $p>0.05$ ). The concentration of TP, ALB, and ALB were in the normal range, which indicates that the animals were in healthy status with no adverse effect on their performance [29]. The concentration of plasma GLU, NEFA, and BUN are directly related to timing of feed intake. NEFA is an indicator of energy balance and increased NEFA indicates lipid mobilization to meet energy demands, and intake time of protein, especially rumen undegraded protein. No significant differences were found in the concentrations of NEFA, BUN, and GLU in cows between groups, which probably demonstrates no potential metabolic changes from being fed on the amount of B. papyrifera silage. The immune system is a complex system regulating group of cells with integrated function essential to health. It is reported that plant flavonoids modulate immune and inflammatory cell functions [30].

In the present study, cows in Group M and Group $\mathrm{H}$ had significantly higher IgA and IgG than those in control group and cows in Group $\mathrm{H}$ had higher IgM than those in control Group, which might be due to the flavonoids in the B. papyrifera silage. Oxidative stress, an imbalance between free radical generation and antioxidant system, is a main contributing factor inducing various diseases in animals [31]. Antioxidant nutrients could be used to reduce the effects of substances that induce reactive oxygen metabolites and to control oxidative stress [32]. Some specific photochemicals isolated from the fruit of B. papyrifera have potent antioxidant effects [1]. Flavonoids are a major class of plant secondary metabolites with multiple functions, such as pigmentation, antimicrobial activity and antioxidant activity [12]. It is reported that they are naturally occurring in bark [33], fruit [15] and leaves [34] of B. papyrifera. SOD is the first line of antioxidant defense that catalysis the conversion of superoxide radical to hydrogen peroxide [35], while CAT is another antioxidant enzyme that can catabolize peroxide to water [36]. 8-Hydroxy-2'deoxyguanosine (8-OHdG) is believed to be one of the most abundant DNA lesions resulting from oxidative stress and is a biomarker of the oxidative DNA damage and repair. The diet 
with $15 \%$ of $B$. papyrifera silage significantly increased concentration of CAT, SOD, and TAC and decreased the serum concentration of 8-OHdG. Phenolic compounds and flavonoids appear to be the main components responsible for the antioxidant activity of $B$. papyrifera silage, and the antioxidant capacity was improved as the supplement level of B. papyrifera silage increased. The efficiency of antioxidative systems against reactive oxygen species is monitored by the estimation of TAC. It is reported that mean TAC levels in shrubs and trees were higher than those in grass, concentrate and timothy hay, and intake of high TAC plants might be beneficial for the TAC status of cattle $[10,11]$. The MDA is a final product of lipid peroxidation. Cows in Group $\mathrm{H}$ had significantly higher TAC than that in control Group, but there was no significant difference between the groups, which is in accordance with results that an increase in TAC is not parallel with an increase in MDA in cows [37]. Supplementation of B. papyrifera silage did not affect the serum concentrations of MDA in dairy cows, which might due to the length of the experiment or the dosage of $B$. papyrifera silage not being in an appropriate range. Some non-enzymatic antioxidants, like GSH-Px, a-tocopherol, $\beta$-carotene and uric acid represent the primary antioxidant capacity of serum [35] and could be used as a tool to evaluate the general nutritional status of animals [38]. In the present study, nutrition didn't appear to have significant effect on the activity of GSH-Px in blood which is in accordance with the studies by Sgorlon et al [39], and it might be sensitive at tissue or cellular level.

\section{Milk fatty acid profiles}

Because of the biohydrogenation occurring in the rumen, milk and other dairy products are a major contributor to dietary saturated fatty acid, which has led to a negative consumer perception and a public health concern related to excessive intake of saturated fats [40]. There have been numerous researches carried out during the last three decades to improve the FA profiles of the products of ruminants [41-44], and there was not enough evidence of direct relationship between PUFA and health, however, further studies indicated PUFA content of the foods did affect some indicators of health status [45-47]. Compared with the control group, milk PUFA of cows are significantly higher $(\mathrm{p}<0.05)$, and saturated fats $(\mathrm{C} 4: 0, \mathrm{C} 17: 0)$ are significantly lower $(\mathrm{p}<0.05)$ in group $M$ and group $H$, which might be caused by the reduced biohydrogenation of unsaturated fatty acids in the rumen. It is reported that the active ingredients of $B$. papyrifera have antibacterial or antimicrobial effect [33], and this might have affected the rumen microflora, which reduced the hydrogenation of FA in the rumen. Dietary PUFA act as precursors for inflammationmediating eicosanoids and resolvins, and represent direct ligands of transcription factors associated to immune response [48-50]. With more PUFA, the milk would be more beneficial for human's health.

\section{CONCLUSION}

B. papyrifera silage could be used as a new feed resource for lactating dairy cows, affecting their antioxidant capacity and the milk components positively. Supplementation with about $10 \%$ to $15 \%$ of B. papyrifera silage might reduce milk SCC, while improving the quality of milk with more PUFA, and improve the immune functions and the antioxidant functions. It could serve as a new feeding resource for silage preparation. Phenolic and flavonoids might be the main components responsible for the antioxidant activity in the B. papyrifera silage which needs further study. Moreover, further investigation is required to investigate the mechanism in which the $B$. papyrifera silage regulates the immune functions and antioxidant functions of dairy cows.

\section{CONFLICT OF INTEREST}

We certify that there is no conflict of interest with any financial organization regarding the material discussed in the manuscript.

\section{ACKNOWLEDGMENTS}

The study was supported by the Earmarked Fund for Beijing Dairy Industry Innovation Consortium of Agriculture Research System (BAIC06-2018), Beijing Key Laboratory for Dairy Cow Nutrition.

\section{REFERENCES}

1. Han Q, Wu Z, Huang B, et al. Extraction, antioxidant and antibacterial activities of Broussonetia papyrifera fruits polysaccharides. Int J Biol Macromol 2016;92:116-24.

2. Lin LW, Chen HY, Wu CR, et al. Comparison with various parts of Broussonetia papyrifera as to the antinociceptive and anti-inflammatory activities in rodents. Biosci Biotechnol Biochem 2008;72:2377-84.

3. Tsai FH, Lien JC, Lin LW, et al. Protective effect of Broussonetia papyrifera against hydrogen peroxide-induced oxidative stress in SH-SY5Y cells. Biosci Biotechnol Biochem 2009;73:1933-9.

4. Guo FJ, Feng L, Huang C, et al. Prenylflavone derivatives from Broussonetia papyrifera, inhibit the growth of breast cancer cells in vitro and in vivo. Phytochem Lett 2013;6:331-6.

5. Lee SH, Yu JH, Jeong CL, Yoon YC, Back YJ. The influence of mastitis on the quality of raw milk and cheese. Korean J Dairy Sci 1999;39:750-60.

6. Mantle D, Eddeb F, Pickering AT. Comparison of relative antioxidant activities of British medicinal plant species in vitro. J Ehnopharmacology 2000;72:47-51. 
7. Jang HD, Chang KS, Huang YS, et al. Principal phenolic phytochemicals and antioxidant activities of three Chinese medicinal plants. Food Chem J 2007;103:749-56.

8. Conforti F, Sosa S, Marrelli M, et al. In vivo anti-inflammatory and in vitro antioxidant activities of Mediterranean dietary plants. J Ehnopharmacol 2008;116:144-51.

9. Xu ML, Wang L, Hu JH, Lee SK, Wang MH. Antioxidant activities and related polyphenolic constituents of the methanol extract fractions from Broussonetia papyrifera stem bark and wood. Food Sci Biotechnol 2010;19:677-82.

10. Haga S, Ishizaki $H$, Nakano $M$, et al. Increase in plasma total antioxidant capacity of grazing Japanese Black heifers and cows in forestland in Japan. Anim Sci J 2014;85:135-42.

11. Haga S, Nakano M, Nakao S, et al. Seasonal foraging patterns of forest-grazing Japanese Black heifers with increased plasma total antioxidant capacity. Anim Sci J 2016;87:209-16.

12. Proestos C, Boziaris IS, Nychas GJE, Komaitis M. Analysis of flavonoids and phenolic acids in Greek aromatic plants: Investigation of their antioxidant capacity and. Food Chem J 2006; 95:664-71.

13. Peluso I, Miglio C, Morabito G, Ioannone F, Serafini M. Flavonoids and immune function in human: a systematic review. Crit Rev Food Sci 2015;55:383-95.

14. Xu Y, Guo ZJ, Tan L, Bu XQ, Long LH. Seasonal variation of total flavonoids contents for different parts of Broussonetia papyrifera. Res Pract Chinese Med 2009;23:16-7.

15. Sun J, Liu SF, Zhang CS. Chemical composition and antioxidant activities of Broussonetia papyrifera fruits. Appl Biol Chem 2012;7:e32021

16. Van Soest PJ, Robertson JB, Lewis BA. Methods for dietary fiber, neutral detergent fiber, and nonstarch polysaccharides in relation to animal nutrition. J Dairy Sci 1991;74:3583-97.

17.Goering HK, Van Soest PJ. Forage fiber analyses (apparatus, reagents, procedures, and some applications). Washington DC, USA: The National Academies Press; 1970.

18. Bligh EG, Dyer WJ. A rapid method of total lipid extraction and purification. Can J Biochem Physiol 1959;37:911-7.

19. Carrapiso AI, Garcia C. Development in lipid analysis: some new extraction techniques and in situ transesterification. Lipids 2000;35:1167-77.

20.Skrzypek R, Wojtowski J, Fahr RD. Factors affecting somatic cell count in cow bulk tank milk--a case study from Poland. J Vet Med 2004;51:127-31.

21. Ruegg PL, Pantoja JCF. Understanding and using somatic cell counts to improve milk quality. Irish J Agric Food Res 2013; 52:101-17.

22.Jin JH, Lim H, Kwon SY, Son KH, Kim HP. Anti-inflammatory activity of the total flavonoid fraction from Broussonetia papyrifera in combination with Lonicera japonica. Biomol Ther 2010;18:197-204.

23. Wang L, Son HJ, Xu ML, Hu JH, Wang MH. Anti-inflammatory and anticancer properties of dichloromethane and butanol fractions from the stem bark of Broussonetia papyrifera. J Korean Soc Appl Biol Chem 2010;53:297-303.

24. Wu WT. Evaluation of anti-inflammatory effects of Broussonetia papyrifera stem bark. Indian J Pharmacol 2012;44:26-30.

25. Auldist MJ, Coats S, Rogers GL, McDowell GH. Changes in the composition of milk from healthy and mastitic dairy cows during the lactation cycle. Aust J Exp Agric 1995;35:427-36.

26. Shirzeyli FH, Lavvaf A, Ghazvinian K. Effect of somatic cell count on the milk yield and chemical composition of Holstein cow milk. Int J Biosci 2015;6:283-91.

27. Kelava N, Kalit S, Havranek J, Konjacic M, Ivankovic A. Effect of somatic cell count on milk composition from individual udder quarters. Milchwissenschaft 2011;66:237-9.

28. Mazal G, Vianna PC, Santos MV, Gigante ML. Effect of somatic cell count on Prato cheese composition. J Dairy Sci 2007;90: 630-6.

29. Radostits OM, Gay CC, Hinchcliff KW, Constable PD. Veterinary Medicine. A textbook of the diseases of cattle, sheep, pigs goats and horses. 10th Edition. London, UK: W.B. Saunders Ltd; 2007.

30. Middleton EJ. Effect of plant flavonoids on immune and inflammatory cell function. Adv Exp Med Biol 1998;439:175-82.

31.Lykkesfeldt J, Svendsen O. Oxidants and antioxidants in disease: oxidative stress in farm animals. Vet J 2007;173:502-11.

32. Miller JK, Brzezinska-Slebodzinska E, Madsen FC. Oxidative stress, antioxidants, and animal function. J Dairy Sci 1993;76: 2812-23.

33. Kai WH, Kou WQ, Cheng Z, Qian SB, Chen YP. Extraction and antimicrobial activity of total flavonoids from cortex of Broussonetia papyrifera. J Anhui Univ Chin Med 2015;34:93-6.

34. Du ZL, Yin ZQ, Wang L, et al. Coumarins and flavonoids from leaves of Broussonetia papyrifera. Nat Prod Res Dev 2008;20: 630-2.

35. Halliwell B, Gutteridge JM. Free radicals in biology and medicine. 4 th Edition. Oxford, UK: Oxford University Press; 2007. $764 \mathrm{p}$.

36. Droge W. Free radicals in the physiological control of cell function. Physiol Rev 2002;82:47-95.

37. Omidi A, Fathi MH, Parker MO. Alterations of antioxidant status markers in dairy cows during lactation and in the dry period. J Dairy Res 2017;84:49-53.

38.Zdunczyk Z, Flis M, Zielinski $\mathrm{H}$, et al. In vitro antioxidant activities of barley, husked oat, naked oat, triticale, and buckwheat wastes and their influence on the growth and biomarkers of antioxidant status in rats. J Agric Food Chem 2006;54:416875.

39. Sgorlon S, Stradaioli G, Gabai G, Stefanon B. Variation of starch and fat in the diet affects metabolic status and oxidative stress in ewes. Small Rumin Res 2008;74:123-9.

40. Mensink RP, Zock PL, Kester AD, Katan MB. Effects of dietary fatty acids and carbohydrates on the ratio of serum total to HDL cholesterol and on serum lipids and apolipoproteins: 
a meta-analysis of 60 controlled trials. Am J Clin Nutr 2003; 77:1146-55

41. Clapperton JL, Kelly ME, Banks JM, Rook JA. The production of milk rich in protein and low in fat, the fat having a high polyunsaturated fatty acid content. J Sci Food Agric 1980;31: 1295-302.

42. Alfaia CM, Quaresma MA, Castro ML, et al. Fatty acid composition, including isomeric profile of conjugated linoleic acid, and cholesterol in Mertolenga-PDO beef. J Sci Food Agric 2006;86:2196-205.

43.Szumacher-Strabel M, Cieslak A, Zmora P, et al. Camelina sativa cake improved unsaturated fatty acids in ewe's milk. J Sci Food Agric 2011;91:2031-7.

44. Girard M, Dohme-Meier F, Silacci P, et al. Forage legumes rich in condensed tannins may increase n-3 fatty acid levels and sensory quality of lamb meat. J Sci Food Agric 2016;96: 1923-33.

45. Diniz YS, Cicogna AC, Padovani CR, et al. Diets rich in satur- ated and polyunsaturated fatty acids: metabolic shifting and cardiac health. Nutrition 2004;20:230-4.

46. Ferrucci L, Cherubini A, Bandinelli S, et al. Relationship of plasma polyunsaturated fatty acids to circulating inflammatory markers. J Clin Endocrinol Metab 2006;91:439-46.

47. Cherubini A, Ruggiero C, Lattanzio F. Polyunsaturated fatty acids and human health: a critical appraisal of the evidence. Curr Pharm Design 2009;15:4085-6.

48. Serhan CN, Chiang N, Van Dyke TE. Resolving inflammation: dual anti-inflammatory and pro-resolution lipid mediators. Nat Rev Immunol 2008;8:349-61.

49. Oh DY, Talukdar S, Bae EJ, et al. GPR120 is an omega-3 fatty acid receptor mediating potent anti-inflammatory and insulinsensitizing effects. Cell 2010;142:687-98.

50. Calder PC. The relationship between the fatty acid composition of immune cells and their function. Prostaglandins Leukot Essent Fatty Acids 2008;79:101-8. 